\title{
Tuberculosis in native- and foreign-born populations in Portugal
}

\author{
J. Paulino,* A. Martins, ${ }^{\dagger}$ M. Machado, ${ }^{\ddagger}$ M. Gomes, ${ }^{\dagger}$ A. R. Gaio, ${ }^{\ddagger \S}$ R. Duarte ${ }^{\dagger \rrbracket * *}$ \\ ${ }^{*}$ Faculty of Medicine, ${ }^{\dagger}$ Epidemiology Unit, Institute of Public Health, ${ }^{\ddagger}$ Department of Mathematic, Faculty of \\ Sciences, and ${ }^{\S}$ Centre of Mathematics, University of Porto, Porto, "Chest Disease Centre, Vila Nova de Gaia, \\ "Pulmonology, Centro Hospitalar de Vila Nova de Gaia/Espinho EPE, **Department of Clinical Epidemiology, \\ Predictive Medicine and Public Health, University of Porto Medical School, Porto, Portugal
}

S U M M A R Y

BACKGROUND: Tuberculosis (TB) is a major global health problem, and during the last 20 years, industrialised countries have shown similar patterns in TB notifications: decreasing TB incidence in native populations and increasing incidence in foreign-born populations.

OBJECTIVES: To characterise risk factors associated with TB among native- and foreign-born TB patients in Portugal and identify barriers to the management of foreign cases.

METHODS: Analysis of the data from the national tuberculosis surveillance system and data from an online survey of physicians managing TB cases in the country. RESULTS: Risk factors in the two populations differed.
Foreign-born patients were younger, less likely to use drugs or alcohol and had fewer comorbidities. They were also more likely to be human immunodeficiency virus positive, to be employed and to be homeless/living in shelters. The outcome of the disease and the time to diagnosis were not significantly different between the two populations. The most important barriers to the management of foreign-born TB cases were language and fear of deportation.

CONCLUSIONS: As there are significant differences between the two populations, different TB control strategies should be implemented in the two populations.

KEY WORDS: TB; foreigners; treatment outcomes
TUBERCULOSIS (TB) is a major global health problem, with an estimated 9 million cases and 1.5 million deaths in 2013 worldwide. ${ }^{1}$ Over the last 20 years, there have been similar changes in overall TB notifications in industrialised countries: decreasing TB incidence in native populations and increasing incidence in foreign-born populations. ${ }^{2-6}$ Methods used to control TB in these populations in different countries vary. In Portugal, 2393 TB cases were diagnosed in 2013, with a notification rate of 22.9 per 100000 population. Although the total number of cases among foreign-born individuals has not increased over the last few years, its incidence has risen relative to the decrease in the number of cases among native individuals. In 2013, $17 \%(n=409)$ of cases were identified in foreign-born subjects, the majority of them being resident in Portugal for $>2$ years. The notification rate in these populations is almost five times greater than in the native population (100.2/100 000), and has been increasing progressively over the years. ${ }^{7}$

In Portugal, TB out-patient centres are responsible for the management of all TB out-patient cases and for the screening of at-risk individuals. All TB patients are diagnosed and treated free of charge, regardless of their country of origin and legal status. ${ }^{8}$

Diagnosis, treatment and screening are all provided at these out-patient centres. If hospitalisation is required, patients are hospitalised in the out-patient centre's area. TB notification is mandatory and includes demographic characteristics, comorbidities, risk behaviours, and clinical, radiological and microbiological information (Sistema de Vigilância da Tuberculose [SVIG-TB], National Tuberculosis Surveillance System).

The aim of the present study was to determine risk factors associated with TB among native- and foreign-born patients between 1 January 2008 and 31 December 2012 in Portugal and to identify possible barriers to the diagnosis, screening and treatment of foreign-born cases.

\section{MATERIAL AND METHODS}

The data were collected from two sources: the National TB Surveillance System and an online survey sent to physicians managing TB cases.

All TB cases notified to the National Tuberculosis Surveillance System between 1 January 2008 and 31

Correspondence to: João Paulino, Faculty of Medicine, University of Porto, Praça de Gomes Teixeira, 4099-002 Porto, Portugal. e-mail: joaot.paulino@sapo.pt

Article submitted 1 June 2015. Final version accepted 15 September 2015. 
Table 1 Tuberculosis cases reported by region of birth, duration of stay and HDI, Portugal, 2008-2012

\begin{tabular}{lc}
\hline & $\begin{array}{c}\text { Tuberculosis cases reported } \\
n(\%)\end{array}$ \\
\hline Region & \\
Africa & $1484(70.9)$ \\
Asia & $104(5)$ \\
North Europe & $2(0.1)$ \\
East Europe & $197(9.4)$ \\
Central Europe & $95(4.5)$ \\
North America & $1(0.04)$ \\
South America & $209(10)$ \\
Residence in Portugal, years & \\
$<2$ & $341(16)$ \\
$\geqslant 2$ & $1408(67)$ \\
Data missing & $343(17)$ \\
HDI & \\
$<$ Portugal HDI & $1397(67)$ \\
$\geqslant$ Portugal HDI & $79(4)$ \\
Data missing & $616(29)$ \\
\hline
\end{tabular}

$\mathrm{HDI}=$ Human Development Index.

December 2012 were identified. We selected all foreign-born patients as cases and randomly selected controls from among native-born patients, at a ratio of 1:2. Study variables included sex, age, employment status, diabetes mellitus (DM) status, other comorbidities (kidney failure, silicosis, lung cancer, etc.), human immunodeficiency virus (HIV) status, alcohol or drug use, incarceration, homelessness or living in a shelter, TB site, chest radiography results, disease outcome, time to diagnosis and duration of treatment. The criteria for exclusion from the study were invalid or missing information. Descriptive statistics are expressed as absolute (relative) frequency of categorical variables and mean \pm standard deviation for continuous variables. The $\chi^{2}$ test was used to compare frequencies of categorical variables; the Student $t$-test was used to compare means of continuous variables between two independent populations. The application of the $t$-test was ensured by the central limit theorem. Multiple logistic regression was performed to identify characteristics distinguishing the two study populations.

Our sample size was large enough to divide the sample population into two groups: a training sample and a test sample (with respectively $70 \%$ and $30 \%$ of the original sample population) to evaluate the classification accuracy of the regression method. ${ }^{9}$ The selection of the best model was based on the likelihood-ratio test, whenever possible, and on the Akaike Information Criterion in all other cases. The model discrimination ability was indicated by the area under the receiver operating characteristic (ROC) curve. $P<0.05$ was considered statistically significant. To better characterise foreign-born cases, the Human Development Index (HDI) - corresponding to the geometric mean of the life expectancy at birth, mean years of schooling/expected years of schooling and the income index of the patient's
Table 2 Tuberculosis cases in foreign-born individuals by decade of entry into Portugal

\begin{tabular}{lc}
\hline & $\begin{array}{c}\text { Tuberculosis cases in } \\
\text { foreign-born individuals } \\
n(\%)\end{array}$ \\
\hline $\begin{array}{c}\text { Portuguese as official language } \\
\text { No }\end{array}$ & \\
Yes & $458(22)$ \\
Decade of entry & $1634(78)$ \\
1930-1939 & \\
$1940-1949$ & $2(0.1)$ \\
$1950-1959$ & $1(0.05)$ \\
$1970-1979$ & $7(0.3)$ \\
$1980-1989$ & $254(12.1)$ \\
$1990-1999$ & $191(9.1)$ \\
$2000-2012$ & $290(13.9)$ \\
Data missing & $1004(48.0)$ \\
\hline
\end{tabular}

country of origin-was taken into account. Patients were classified as having an equal, higher or lower HDI than native-born cases, as this was considered to be a convenient way to group foreigners according to important TB-related factors.

We also conducted an anonymous online survey of physicians at all TB out-patient centres to identify factors perceived by them to be barriers to the diagnosis, treatment and screening for TB among foreign-born patients. The variables collected included fear of deportation, fear of discrimination, health care costs, social and/other religious differences, literacy, lack of information, difficulty in accessing health care and language.

Ethical approval for the online survey was obtained from the ethics committee of the Institute of Public Health, University of Porto, Porto, Portugal. As retrospective surveillance data were used, with no possibility of linking patient records to patient personal data, ethical approval was not deemed necessary for this retrospective study.

\section{RESULTS}

We analysed 4131 native-born and 2009 foreign-born cases. The majority of the foreign-born individuals came from Africa $(n=1484,73.9 \%)$, followed by South America $(n=209,10.4 \%)$, Eastern Europe $(n=$ $197,9.8 \%)$ and Asia ( $n=104,5.2 \%$ ) (Table 1); 1004 $(48 \%)$ had arrived between 2000 and 2012, and 290 (14\%) between 1990 and 2000. The majority of the foreign-born cases $(n=1408,67 \%)$ had lived in Portugal for $>2$ years before the date of diagnosis. Only 79 (4\%) immigrants with TB had arrived from a country with an HDI greater than or equal to that of Portugal (Tables 1 and 2).

The number of $\mathrm{TB}$ cases in the immigrant population by year of entry into Portugal fell between 2008 and 2012, from 19.76 cases/year of entry/ 100000 in 2008 to 10.31 in 2012 . However, the total 
Table 3 TB cases in foreign-born persons by year

\begin{tabular}{cccc}
\hline & $\begin{array}{c}\text { Foreign-born } \\
\text { TB cases } \\
\text { in the first year } \\
\text { after arrival }\end{array}$ & $\begin{array}{c}\text { Total foreign-born } \\
\text { TB cases diagnosed } \\
\text { each year }\end{array}$ \\
\hline 2008 & 440277 & 87 & 408 \\
2009 & 454191 & 101 & 438 \\
2010 & 445262 & 85 & 432 \\
2011 & 436822 & 60 & 410 \\
2012 & 417042 & 43 & 404 \\
\hline
\end{tabular}

$\mathrm{TB}=$ tuberculosis number of TB cases diagnosed each year remained almost the same (Table 3).

Patient characteristics are given in Table 4. From the multiple logistic regression analysis, male sex, HIV positivity, employment status and homelessness/ living in a shelter (vs. age, other comorbidities, drug use) were positively (vs. negatively) associated with being foreign-born. More precisely, the model predicted the odds of being a foreign-born $\mathrm{TB}$ case among the HIV-positive population (vs. the em-

Table 4 Patient characteristics by regression analysis

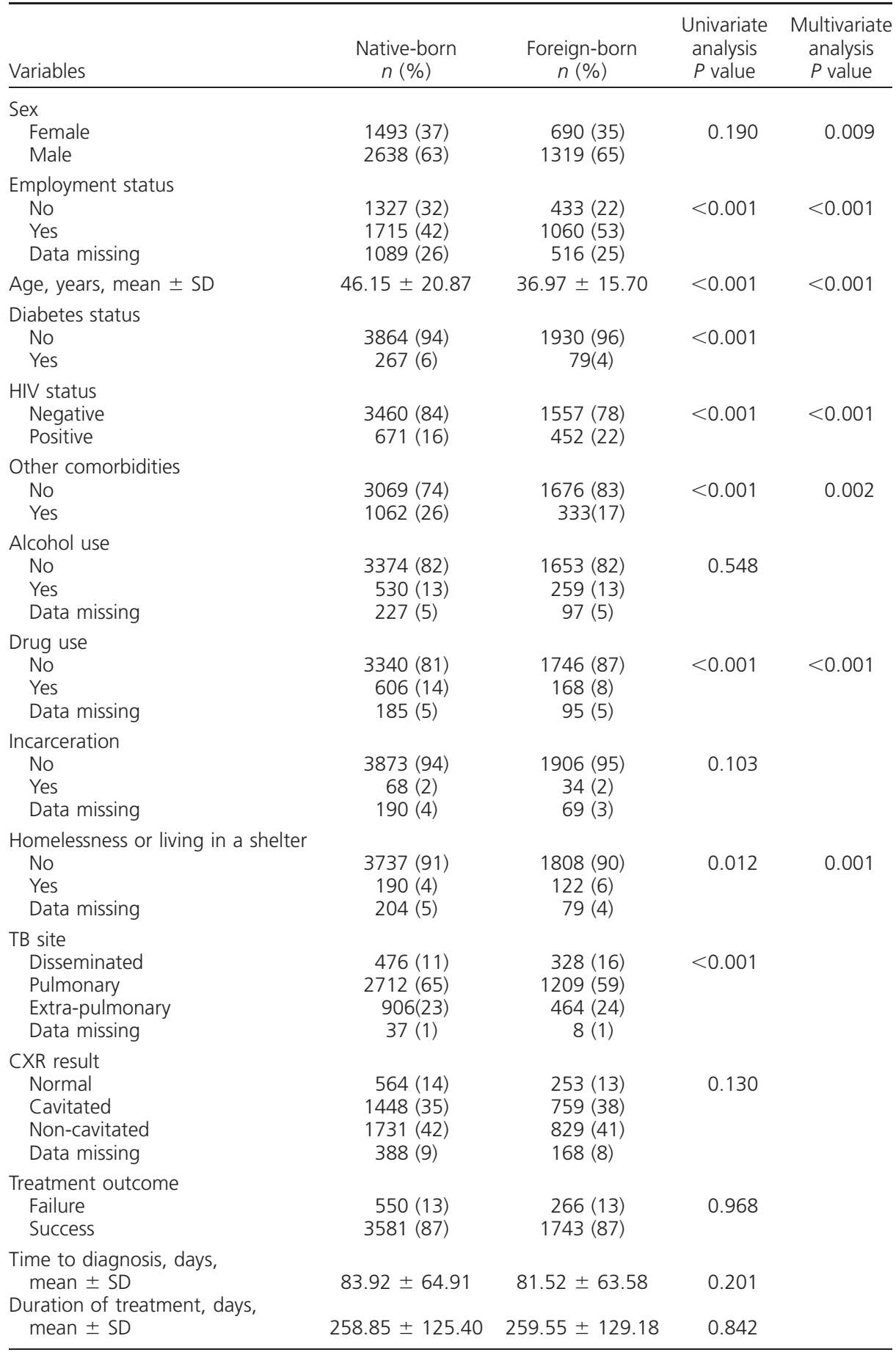

$\mathrm{SD}=$ standard deviation; HIV = human immunodeficiency virus; $\mathrm{TB}=$ tuberculosis; $\mathrm{CXR}=$ chest radiography. 
Table 5 Results of multiple logistic regression model in foreign-born patients*

\begin{tabular}{lc}
\hline Variables & OR $(95 \% \mathrm{Cl})$ \\
\hline Intercept & $0.161(-0.099$ to 0.420$)$ \\
Male sex & $0.209(0.0352$ to 0.383$)$ \\
Age & $-0.030(-0.035$ to -0.025$)$ \\
Employed & $0.381(0.200$ to 0.564$)$ \\
HIV positivity & $0.742(0.500$ to 0.986$)$ \\
Other comorbidities & $-0.340(-0.571$ to -0.114$)$ \\
Drug abuse & $-1.140(-1.499$ to -0.796$)$ \\
Homelessness/living in a shelter & $0.790(0.294$ to 1.274$)$
\end{tabular}

* AIC $=3440.101$.

$\mathrm{OR}=$ odds ratio; $\mathrm{Cl}=$ confidence interval; $\mathrm{HIV}=$ human immunodeficiency virus; $\mathrm{AIC}=$ Akaike Information Criterion.

ployed) to be approximately double (vs. $50 \%$ higher) than among native-born HIV-positive cases (vs. the unemployed). Moreover, the odds of being a foreignborn TB case among drug users (vs. those with other comorbidities) was about 70\% lower (vs. 30\% lower) than among those TB cases with no drug use (vs. those with no comorbidities). Finally, being a foreignborn TB case was significantly associated with young age (each 10-year increase in age was estimated to produce a $30 \%$ reduction of the odds), while homeless cases or those living in shelters were more likely to be immigrants (Tables 5 and 6). The model had a classification error of $24 \%$ and an area under the ROC curve of $69 \%$.

The mean time between onset of symptoms and diagnosis (time to diagnosis) was predicted to be slightly (approximately 4 days), although not significantly, longer among native-born TB cases, while the duration of treatment was slightly longer among foreigners (2 days). This outcome was not found to have a significant effect on time to diagnosis (Table 7).

Risk factors significantly associated with longer time to diagnosis were male sex, having DM, being HIV-negative, not being a drug user, incarceration, homelessness/living in a shelter and having extrapulmonary TB (Table 7).

The rate of response to the online survey among physicians was $64 \%(35 / 55)$. The main barriers to diagnosis as perceived by the respondents were language, fear of deportation, fear of discrimination and lack of information. The main obstacles to

Table 6 ORs and 95\%Cls from the multiple logistic regression model in foreign-born patients

\begin{tabular}{lc}
\hline Variables & OR $(95 \% \mathrm{Cl})$ \\
\hline Male sex & $1.232(1.043-1.507)$ \\
Age & $0.970(0.965-0.975)$ \\
Employed & $1.469(1.211-1.781)$ \\
HIV positivity & $2.137(1.647-2.773)$ \\
Other comorbidities & $0.711(0.225-0.454)$ \\
Drug use & $0.336(0.235-0.482)$ \\
Homelessness or living in a shelter & $2.193(1.346-3.574)$ \\
\hline
\end{tabular}

$\mathrm{OR}=$ odds ratio; $\mathrm{Cl}=$ confidence interval; $\mathrm{HIV}=$ human immunodeficiency virus.
Table 7 Descriptive statistical measures of the mean time to diagnosis (for each category of a factor and the correlation coefficient for each continuous variable)

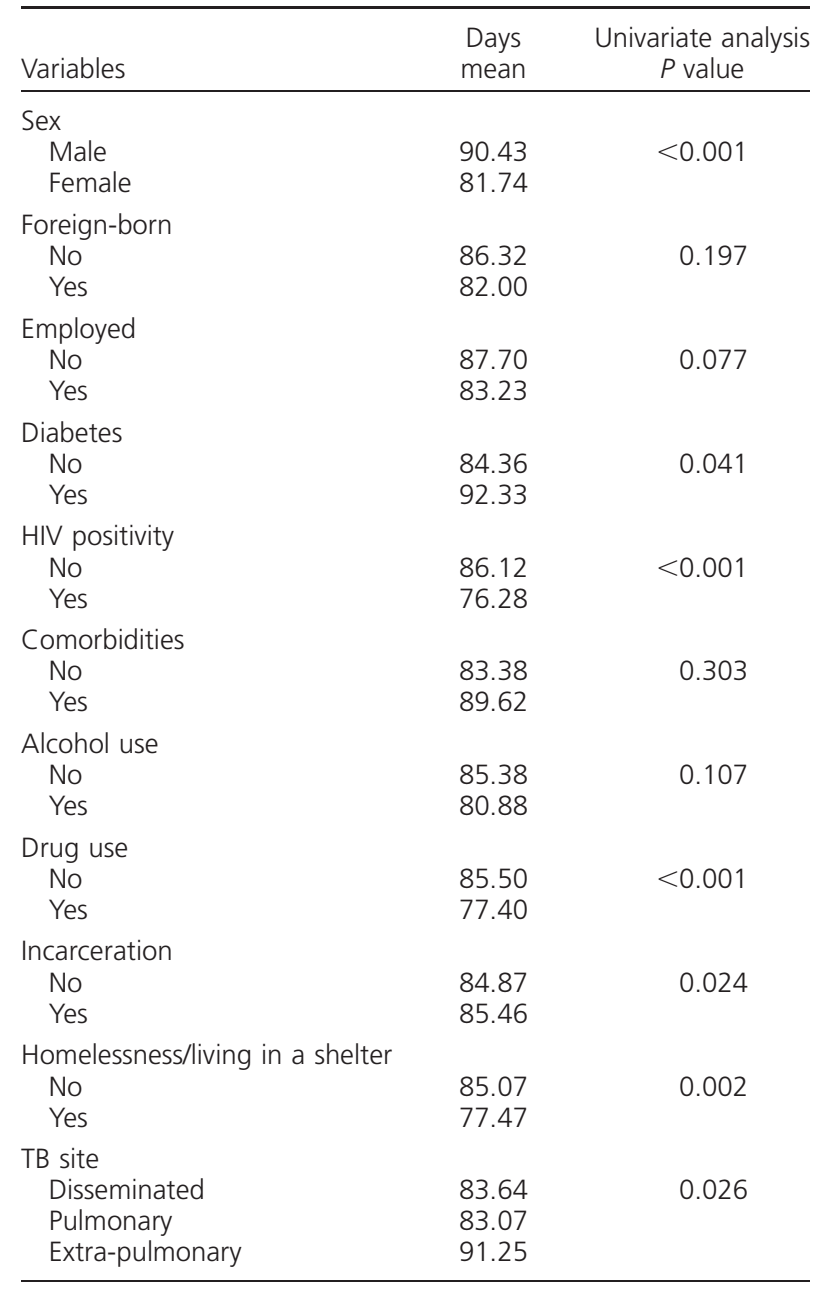

HIV = human immunodeficiency virus; TB = tuberculosis.

treatment were language and fear of discrimination. Language and lack of information were the main barriers to TB screening (Table 8).

\section{DISCUSSION}

Like the majority of Western European countries, Portugal has experienced a stable trend in TB incidence over the last 10 years, although, unlike other Western countries, it is an intermediate TB incidence country. ${ }^{1,7}$ Although there are no highincidence districts $(\geqslant 50$ cases $/ 100000)$, there are five districts with intermediate incidence ( $>20$ cases/ $100000)$, two of which are the main urban areas (Oporto and Lisbon) in the country, with more than 40 cases $/ 100000 .{ }^{7}$ Of the two regions, immigration is clearly more prevalent in Lisbon for geographic and economic reasons.

The main findings of our study were as follows: 1 ) foreign-born populations do not share the same risk factors as native populations; and 2) risk factors 
Table 8 Physicians' perceived barriers to diagnosis, treatment and screening among the foreign-born

\begin{tabular}{lccr}
\hline Variables & $\begin{array}{c}\text { Diagnosis } \\
n(\%)\end{array}$ & $\begin{array}{c}\text { Treatment } \\
n(\%)\end{array}$ & $\begin{array}{c}\text { Screening } \\
n(\%)\end{array}$ \\
\hline Fear of deportation & $15(43)$ & $15(43)$ & $13(37)$ \\
$\begin{array}{l}\text { Fear of discrimination } \\
\text { Health care costs }\end{array}$ & $15(43)$ & $11(31)$ & $13(37)$ \\
$\begin{array}{l}\text { Cultural/religious } \\
\quad \text { differences }\end{array}$ & $7(20)$ & $8(23)$ & $7(20)$ \\
$\begin{array}{l}\text { Literacy } \\
\text { Lack of information }\end{array}$ & $10(29)$ & $7(20)$ & $7(20)$ \\
$\begin{array}{l}\text { Problems in accessing } \\
\quad \text { health care units }\end{array}$ & $15(43)$ & $4(11)$ & $5(14)$ \\
$\begin{array}{l}\text { Language (in case of } \\
\quad \text { non-Portuguese- }\end{array}$ & $11(31)$ & $11(31)$ & $9(26)$ \\
$\quad$ & & & \\
speaking cases) & $24(69)$ & $24(69)$ & $20(57)$ \\
\hline
\end{tabular}

among the foreign-born cases are male sex, being employed, HIV infection and homelessness. The risk factors among Portuguese populations as described in the literature are drugs and alcohol use, HIV infection and homelessness. ${ }^{10}$ In our sample, most of the foreign-born TB cases were younger and were less likely to be drug users; there were no differences in alcohol use; foreign-born cases were more likely to be HIV-positive and were more often employed than native-born cases. These findings are compatible with a large systematic review conducted in Italy, where it was found that drug and alcohol use do not appear to be risk factors for TB in immigrants, mainly due to cultural and/or religious traditions. ${ }^{11}$ A study conducted in Spain also reports results similar to ours, with drug use and HIV positivity being lower in a group of immigrants between 2005 and 2007. ${ }^{12}$ Data from Tel Aviv, Israel, have also shown that foreignborn cases are usually younger, less likely to smoke or use alcohol or other drugs and more likely to be employed when diagnosed. ${ }^{13}$

Despite the differences between the two populations, we failed to identify any significant differences in outcomes between native- and foreign-born TB cases. These findings are substantially different from those published recently. A French and a Finnish study reported worse treatment outcomes in foreignborn cases than in native-born cases, ${ }^{14,15}$ while a study from Israel reported that being Israeli-born was associated with a higher treatment success rate. ${ }^{13}$ In Turkey, being foreign-born was associated with a five-fold risk of adverse treatment outcomes. ${ }^{16}$ The present study suggests that, in Portugal, the foreignborn population is treated as effectively as the nativeborn population.

According to our study results, there was no delay in diagnosis in foreign-born patients when compared to native-born patients. Some previously published papers have reported the opposite, as foreign-born persons tend to ignore the initial signs and symptoms of the disease, leading to serious delays in diagnosis and treatment. ${ }^{17-20}$ Studies reported that these patients were self-diagnosed and self-treated, using private clinics and pharmacies before public health facilities. ${ }^{21}$ Mor et al. also reported a longer than average delay in diagnosing foreign-born patients in Israel, where being asymptomatic or a smoker also contributed to a longer time to TB diagnosis; in our study, male sex, having DM, being HIV-negative, not being a drug user, incarceration, homelessness/living in a shelter and having extra-pulmonary TB were risk factors associated with delayed diagnosis. ${ }^{13}$ The absence of legal or economic barriers to TB diagnosis and treatment-everyone can be diagnosed and treated free of charge, regardless of country of origin or legal status-may have had an important impact on the results.

The online survey showed that TB physicians believed that the main barriers to the management of foreign-born TB cases were language and patients' fear of deportation. Abarca et al. in Spain reported similar barriers: illiteracy or lack of familiarity with the language and social consequences of the disease. ${ }^{20}$

Our study had several limitations: despite the above conclusions, we are aware of the occasional lack of clinical significance among the identified statistical comparisons as a weakness in our study. This is primarily due to the large sample size, which is more likely to lead to a rejection of the null hypothesis than a smaller sample size. Moreover, a joint study of the separately identified risk factors for time to diagnosis was not possible due to severe lack of normality among errors of the multiple linear regression model. However, the study also had several strengths: the length of the study, the large sample size and data completeness (the study was based on the published national reports available in November of the year following the year of reporting).

\section{CONCLUSIONS}

Risk factors were different in the two populations: foreign-born patients were more likely to be younger and less likely to be drug users, more likely to be HIVpositive and more likely to be employed than nativeborns, who were more likely to use drugs and alcohol.

However, despite these differences, treatment outcomes and time to diagnosis were not significantly different between the two populations-the free access to diagnosis and treatment may have had an important impact on this. TB physicians face two main barriers when dealing with foreign-born patients-language and the fear of deportation.

\section{Acknowledgements}

ARG was partially supported by Centro de Matemática da Universidade do Porto, Porto (UID/MAT/00144/2013), which is 
funded by Fundação para a Ciência e a Tecnologia, Lisbon, Portugal) with national (Ministro da Educação e Ciência) and European structural funds through the Fonds européen de développement régional programmes, under the PT2020 partnership agreement.

Conflicts of interest: none declared.

\section{References}

1 World Health Organization. Global tuberculosis report, 2013. WHO/HTM/TB/2013.11. Geneva, Switzerland: WHO, 2013.

2 Pareek M, Baussano I, Abubakar I, Dye C, Lalvani A. Evaluation of immigrant tuberculosis screening in industrialized countries. Emerg Infect Dis 2012; 18: 1422 1429.

3 Svensson E, Millet J, Lindqvist A, et al. Impact of immigration on tuberculosis epidemiology in a low-incidence country. Clin Microbiol Infect 2011; 17: 881-887.

4 European Centre for Disease Prevention and Control. Tuberculosis surveillance and monitoring in Europe. Stockholm, Sweden: ECDC, 2014.

5 Fenner L, Gagneux S, Helbling P, et al. Mycobacterium tuberculosis transmission in a country with low tuberculosis incidence: role of immigration and HIV infection. J Clin Microbiol 2012; 50: 388-395.

6 Lombardi G, Dal Monte P, Denicolo A, et al. Trend of microbiologically-confirmed tuberculosis in a low-incidence setting with high immigration rates. BMC Public Health 2014; 14: 340 .

7 Programa Nacional para a Infeção VIH SeT. Portugal infeção VIH, SIDA e Tuberculose em números. Lisbon, Portugal: Direcção-Geral da Saúde, 2014. [Portuguese]

8 Correia C. Acesso de cidadãos estrangeiros, em situação documental irregular, com diagnóstico provável ou confirmado de tuberculose. Lisbon, Portugal: Ministério da Saúde, 2013. [Portuguese]

9 Hastie T, Tibshirani R, Friedman J. The elements of statistical learning: data mining, inference, and prediction. New York, NY, USA: Springer, 2009.
10 Portugal Ministério da Saúde. Programa nacional de luta contra a tuberculose: STOP TB. Lisbon, Portugal: Ministério da Saúde de Portugal, 2012. [Portuguese]

11 Ingrosso L, Vescio F, Giuliani M, et al. Risk factors for tuberculosis in foreign-born people (FBP) in Italy: a systematic review and meta-analysis. PLOS ONE 2014; 9: e94728.

12 Iñigo J, García de Viedma D, Arce A, et al. Differential findings regarding molecular epidemiology of tuberculosis between two consecutive periods in the context of steady increase of immigration. Clin Microbiol Infect 2012; 19: 292-297.

13 Mor Z, Kolb H, Lidji M, Migliori G, Leventhal A. Tuberculosis diagnostic delay and therapy outcomes of non-national migrants in Tel Aviv, 1998-2008. Euro Surveill 2013; 18: 20433.

14 Antoine D, Che D. Treatment outcome monitoring of pulmonary tuberculosis cases notified in France in 2009. Euro Surveill 2013; 18: 20434.

15 Vasankari T, Holmstrom P, Ollgren J, Liippo K, Kokki M, Ruutu P. Risk factors for poor tuberculosis treatment outcome in Finland: a cohort study. BMC Public 2007; 7: 291.

16 Babalik A, Kilicaslan Z, Kiziltas S, Gencer S, Ongen G. A retrospective case-control study, factors affecting treatment outcomes for pulmonary tuberculosis in Istanbul, Turkey. Balkan Med J 2013; 30: 204-210.

17 Wei X, Chen J, Chen P, et al. Barriers to TB care for rural-tourban migrant TB patients in Shanghai: a qualitative study. Tropical Med Int Health 2009; 14: 754-760.

18 Sagbakken M, Bjune G, Frich J. Experiences of being diagnosed with tuberculosis among immigrants in Norway-factors associated with diagnostic delay: a qualitative study. Scand J Public Health 2010; 38: 283-290.

19 Huffman S A, Veen J, Hennink M M, McFarland D A. Exploitation, vulnerability to tuberculosis and access to treatment among Uzbek labor migrants in Kazakhstan. Soc Sci Med 2012; 74: 864-872.

20 Abarca Tomas B, Pell C, Bueno Cavanillas A, Guillen Solvas J, Pool R, Roura M. Tuberculosis in migrant populations. A systematic review of the qualitative literature. PLOS ONE 2013; 8: e82440.

21 Ho M J. Migratory journeys and tuberculosis risk. Med Anthropol Q 2003; 17: 442-458. 
CADRE : La tuberculose (TB) est un problème majeur de santé publique dans le monde, et au cours des 20 dernières années, les pays industrialisés ont montré un profil similaire de déclaration de la TB : une diminution de l'incidence dans la population autochtone et une augmentation de l'incidence dans la population née à l'étranger.

O В JECTIF : Caractériser les facteurs de risque associés à la TB au Portugal parmi des patients tuberculeux autochtones et nés à l'étranger et identifier les entraves à la prise en charge des cas étrangers.

MÉTHODE : L'analyse des données du système national de surveillances de la TB et d'une enquête en ligne auprès des médecins qui prennent en charge les cas de TB dans le pays.

RÉSULTATS: Les facteurs de risque se sont avérés différents dans les deux populations. Les patients étrangers ont été plus jeunes, moins enclins à consommer des drogues ou de l'alcool et ont eu moins de comorbidités. Ils étaient également plus souvent positifs pour le virus de l'immunodéficience humaine, ils avaient plus souvent un travail et étaient plus souvent sans domicile fixe/hébergés dans des abris. L'évolution de la maladie et le délai de diagnostic n'ont pas été significativement différents entre les deux populations. Les obstacles les plus importants à la prise en charge d'un cas de TB né à l'étranger ont été le langage et la crainte de la déportation.

CONCLUSION : Comme des différences significatives ont été détectées entre les deux populations, différentes stratégies de lutte contre la TB doivent être mises en œuvre.

\section{RE S U M E N}

MARCO DEREFERENCIA: La tuberculosis (TB) es uno de los principales problemas de salud en el mundo y en los últimos 20 años la notificación de la enfermedad en los países industrializados ha presentado un perfil uniforme, con una disminución de la incidencia en la población natural del país y un aumento de la misma en la población nacida en el extranjero.

OBJETIVOS: Caracterizar los factores de riesgo de contraer la TB de las personas naturales del país y las personas nacidas en el extranjero en Portugal y definir los obstáculos al tratamiento de los casos provenientes del extranjero.

MÉTODOS: Se analizaron los datos del Sistema Nacional de Vigilancia de la TB y los resultados de una encuesta administrada en línea a los médicos que se ocupan del tratamiento de los casos de TB en el país. RESULTADOS: Se observaron diferencias en los factores de riesgo de contraer la enfermedad en ambas poblaciones. Los pacientes nacidos en el extranjero eran más jóvenes, con menor probabilidad de abuso de drogas o de alcohol y presentaban menos enfermedades concomitantes. En las personas de este grupo se observaron más casos de positividad frente al virus de la inmunodeficiencia humana, una mayor tasa de empleo y la TB se asoció con la carencia de hogar y la residencia en albergues. No se encontraron diferencias significativas en las dos poblaciones con respecto al desenlace clínico y el lapso hasta el diagnóstico. El principal obstáculo al tratamiento de la TB en las personas nacidas en el extranjero fue el idioma y el temor a la deportación.

CONCLUSIÓN: Habida cuenta de las diferencias considerables observadas en ambas poblaciones, es necesario aplicar diferentes estrategias de control de la infección tuberculosa. 